\title{
Perdamaian Gejolak Pencabutan Izin \\ Rumah Ibadah Di Bantul
}

\section{(Tinjauan Dialektika Kepentingan Agama \\ Dan Hukum Negara)}

\author{
Enggar Wijayanto \\ Fakultas Syariah dan Hukum, \\ Universitas Islam Negeri Sunan Kalijaga Yogyakarta \\ enggarwijayanto19@gmail.com \\ Wahidul Halim \\ Fakultas Syariah dan Hukum, \\ Universitas Islam Negeri Sunan Kalijaga Yogyakarta \\ halimwahidul@gmail.com \\ Faiq Tobroni \\ Fakultas Syariah dan Hukum, \\ Universitas Islam Negeri Sunan Kalijaga Yogyakarta \\ faiq.tobroni@uin-suka.ac.id
}

\begin{abstract}
Sometimes when a permit for house of worship is revoked in one religion, the issue that arises is intolerance from the majority religious interest groups towards minorities. This kind of impression has also been heard when there was a church license revocation in Bantul, where there was a narrative that the Muslim majority group was intolerant towards Christian minority groups. This research found that the revocation of the permit for places of worship was legality under statutory regulations, which in this case it is the Bantul Regent Regulation. Although indeed it is debatable. But at the very least, the use of state law as a consideration for revoking a religious place of worship is a strategy to avoid prolonged inter-religious conflict.
\end{abstract}

Keywords: Conflict, House of Worship, and State Law. 


\begin{abstract}
Abstrak: Terkadang ketika terjadi pencabutan izin rumah ibadah pada salah satu agama, maka isu yang mencuat adalah intoleransi dari kelompok kepentingan agama mayoritas terhadap minoritas. Kesan seperti ini juga pernah terdengar ketika terjadi pencabutan izin gereja di Bantul, yang mana ada narasi kelompok mayoritas Islam telah bersikap intoleran terhadap kelompok minoritas Kristen.Penelitian ini menemukan bahwa pencabutan izin rumah ibadah tersebut mempunyai legalitas secara peraturan perundang-undangan, yang mana dalam hal ini adalah Peraturan Bupati Bantul. Semangat pengaturan atas persyaratan pendirian rumah ibadah yang dibawa Peraturan Bupati tersebut merupakan representasi pelaksanaan beberapa persyaratan pembatasan kegiatan keagamaan sebagaimana diatur dalam UUD 1945, UU Pokok HAM di Indonesia dan International Covenant on Political and Social Rigths. Walaupun memang itu bisa diperdebatkan. Tetapi paling tidak, penggunaan alasan hukum Negara sebagai pertimbangan pencabutan rumah ibadah suatu agama menjadi strategi menghindari terjadinya konflik antar umat beragama secara berkepanjangan.
\end{abstract}

Kata Kunci: Konflik, Rumah Ibadah, dan Hukum Negara.

\title{
A. Pendahuluan
}

Indonesia merupakan negara dengan tingkat kemajemukan tertinggi di dunia, baik dalam hal perbedaan suku, agama, ras, dan budaya. Semua perbedaan yang ada di Indonesia disatukan dengan ideologi Pancasila sebagai falsafah dasar negara. Dikarenakan tingkat heterogenitas yang tinggi menyebabkan Indonesia sangat rawan untuk memunculkan sebuah konflik khususnya menyangkut suku, ras, dan agama (SARA). Namun demikian di Indonesia mayoritas penduduknya memeluk agama Islam dengan jumlah yang besar, hal tersebut tidak serta membuat Indonesia menjadi sebuah negara dengan berlandaskan pada nilai-nilai agama Islam saja. Indonesia menetapkan fondasi negaranya berdasarkan prinsip ketuhanan, sesuai dengan bunyi Sila Pertama "Ketuhanan Yang Maha Esa". Dengan demikian, negara secara tegas tidak hanya mengakui satu agama saja. Namun, Negara mengakui juga agama/kepercayaan lain yang ada di Indonesia dan juga melindungi setiap warga negaranya dalam memilih dan menjalankan agama/kepercayaannya masing-masing. Hal tersebut sesuai dengan Konstitusi Negara yaitu Undang-Undang Dasar 1945 Pasal 29 Ayat (2) yang berbunyi 'Negara menjamin kemerdekaan 
tiap-tiap penduduk untuk memeluk agamanya masing-masing dan beribadat menurut agamanya dan kepercayaannya itu ". ${ }^{1}$

Meskipun Indonesia telah memiliki Pancasila sebagai dasar negara yang mempersatukan berbagai latar belakang dan kepentingan, pada sisi realitasnya masih terdapat banyak hambatan serta masalah yang berkaitan tentang hubungan agama dengan negara, dan hubungan antar umat beragama. Munculnya stereotip satu kelompok terhadap kelompok lain yang berbeda agama biasanya menjadi pemicu konflik antar umat beragama yang diikuti oleh upaya saling serang, saling membunuh, membakar rumah-rumah ibadah, dan tempat-tempat bernilai tinggi bagi masing-masing pemeluk agama ${ }^{2}$. Persoalan seperti ini mengundang pertanyaan yang cukup kompleks yaitu bagaimana eksistensi sebuah negara dengan konstitusinya yang dianggap sebagai kedaulatan tertinggi berdasarkan konsensus seluruh elemen bangsa, serta bagaimana status Islam sebagai sebuah agama yang memiliki fragmentasi dominan dalam mewarnai unsur kenegaraan Indonesia dan menyikapi multikulturalisme yang ada, khususnya konteks kebebasan beragama.

Dari pemaparan diatas maka dapat kita temukan sebuah permasalahan yang dilematis, dimana dalam satu sisi negara harus hadir sebagai wadah sekaligus pelindung bagi seluruh warganya dengan beragam latar belakang dan kepentingan yang diakomodasi dalam Konstitusi sebagai jaminan yang di dalamnya memuat Hak Asasi Manusia (HAM) secara universal tanpa memandang identitas. Di sisi lainya fakta tidak bisa dibantah lagi bahwa Islam dan pemeluknya merupakan mayoritas warga yang hidup di Indonesia, tentunya sebagai mayoritas memiliki kapasitas yang lebih besar untuk menjalankan unsurunsur kenegaraan serta fungsi sosial dalam menengahi perbedaan yang ada sebagai landasan mewujudkan keadilan bersama. Pemaparan di atas mengundang minat penulis untuk menganalisa lebih lanjut tentang tragedi potensi intoleransi keberagamaan yang disebabkan adanya gejolak pencabutan izin gereja di Bantul. Kasus itu bermula dengan adanya Surat Keputusan Bupati Bantul yang mencabut izin sebuah

\footnotetext{
${ }^{1}$ Pasal 29 Ayat (2) Undang - Undang Dasar 1945.

2 Firdaus M. Yunus. "Konflik Agama Di Indonesia Problem Dan Solusi Pemecahannya". Substantia, Volume 16 Nomor 2, Oktober 2014, hlm, 217.
} 
gereja karena tidak sesuai dengan Izin Mendirikan Bangunan. Sempat terjadi ketegangan, yang mana pendeta atau pemimpin jemaat gereja tersebut melakukan gugatan kepada Pengadilan. Namun pada akhirnya, dengan adanya perdamaian antara pendeta dengan Bupati Bantul, akhirnya gugatan tercebut dicabut dan bahkan ada solusi penyediaan pembangunan gereja di lokasi baru. Akan tetapi, yang disayangkan adanya narasi penolakan keberadaan gereja tersebut karena alasan keberadaan gereja tersebut mengancam keimanan penduduk sekitar. Tulisan ini mengajak membawa perspektif penggunaan narasi yang tepat dalam menyampaikan keberatan atas pelaksanaan keagamaan. Beberapa oknum yang penyampaian keberatannya dengan menggunakan alasan hukum agamanya (dalam kasus ini penduduk sekitar gereja yang beragama Islam) justru menimbulkan stigma negatif terhadap keberadaan agamanya sendiri. Sebab nanti akan diklaim sebagai kelompok yang intoleran. Oleh sebab itulah perlu menggunakan narasi yang tepat dalam menyampaikan keberatan atas pelaksanaan keagamaan, yang dalam hal ini harus menggunakan perspektif hukum Negara. Dengan demikian, rumusan masalah penelitian ini adalah bagaimana narasi hukum Negara yang bisa digunakan dalam rangka mendialektikakan antara kepentingan hukum agama dan Negara untuk pencabutan izin rumah ibadah, yang dalam kasus ini kebetulan adalah gereja di Bantul?

\section{B. Pembahasan}

\section{Jaminan Konstitusional Dalam Kebebasan Beragama Di In- donesia.}

Sebagai negara hukum, Indonesia tentu memiliki kaidah-kaidah yang menjadi dasar dalam penyelenggaraan kehidupan berbangsa dan bernegara. Kaidah yang disusun dengan tetap memperhatikan nilai-nilai luhur bangsa Indonesia itu sendiri. Sehingga hal tersebut bisa disepakati oleh semua elemen bangsa yang bisa kita sebut dengan istilah "Konstitusi". Konstitusi adalah hukum tertinggi dalam hierarki peraturan yang ada di suatu negara, yang artinya tidak boleh ada hukum atau peraturan turunan dibawahnya yang bertentangan dengan peraturan diatasnya. Undang-Undang Dasar 1945 adalah konstitusi negara Indonesia. UUD 
1945 terdiri dari $16 \mathrm{Bab}$, dengan 37 Pasal berserta aturan peralihan. Namun, di sini yang penulis ingin kritisi adalah terkait Pasal 29 Bab XI, Tentang Agama. Pasal 29 ayat 1 menjelaskan bahwa "Negara berdasar atas Ketuhanan Yang Maha Esa"3, sedangkan ayat 2 menyebutkan bahwa "Negara menjamin kemerdekaan tiap-tiap penduduk untuk memeluk agamanya masing-masing dan untuk beribadat menurut agamanya dan kepercayaanya itu". ${ }^{4}$ Sehingga bisa dipahami secara seksama bahwa di dalam Konstitusi kita Pertama, negara Indonesia adalah negara yang hidup dengan berdasar pada prinsip Ketuhanan. Dalam hal seperti ini negara bukanlah berdasarkan pada suatu ajaran atau nilai agama tertentu saja, akan tetapi mengakui agama-agama lain serta berusaha mewujudkan perlindungan bagi setiap agama dan pemeluknya sesuai dengan hakhaknya di depan hukum. Berlakunya suatu konstitusi sebagai hukum dasar yang mengikat didasarkan atas kekuasaan tertinggi atau prinsip kedaulatan yang dianut suatu negara. ${ }^{5}$ Rakyat Indonesia menghendaki Pancasila sebagai dasar negara serta UUD 1945 sebagai Konstitusi. Hal demikian dipilih sebagai solusi dalam menyikapi keanekaragaman yang ada di Indonesia.

Di sebuah negara, konstitusi memiliki kedaulatan yang tidak bisa dibenturkan dengan apapun. Indonesia menganut Teori Kedaulatan Hukum. Menurut teori ini, hukum adalah pernyataan penilaian yang terbit dari kesadaran hukum manusia. Hukum merupakan sumber kedaulatan. Kesadaran hukum inilah yang membedakan mana yang adil dan mana yang tidak adil. Teori ini dipakai oleh Indonesia dengan mengubah Undang-Undang Dasarnya, dari konsep kedaulatan rakyat yang diwakilkan menjadi kedaulatan hukum. Teori ini dipakai di indonesia dengan mengubah Undang - Undang Dasarnya, dari konsep kedaulatan rakyat yang diwakilkan menjadi kedaulatan hukum. Kedaulatan tercantum dalam UUD 1945 "Kedaulatan ada di tangan rakyat dan dilaksanakan oleh Undang - Undang Dasar. ${ }^{6}$ Salah satu tokoh

${ }^{3}$ Pasal 29 Ayat 1 Undang - Undang Dasar 1945

4 Pasal 29 Ayat 2 Undang - Undang Dasar 1945

5 Jimly Asshiddiqie. Pengantar Ilmu Hukum Tata Negara Jilid I (Jakarta: Sekretariat Jenderal dan Kepaniteraan MK RI, 2006), hlm.117.

${ }^{6}$ King Faisal Sulaiman, Teori dan Hukum Konstitusi (Bandung: Nusa Media, 
yang berpandangan dengan teori kedaulatan hukum adalah Hugo Krabe. Teori tersebut menggambarkan hukum atau kaitannya dengan Konstitusi berada dalam posisi tertinggi untuk mengatur jalannya sebuah negara. Konstitusi adalah konsensus tertinggi dari segenap elemen bangsa. Menjadi sebuah keharusan bagi semua pihak untuk tunduk terhadap Konstitusi selama di dalamnya memuat hal-hal yang melindungi serta menjamin hak-hak dasar setiap warganya. Tentu pengamalan dari apa yang terkandung di dalamnya didasarkan pada kesadaran hukum dalam diri individu. Di sisi lain penulis memiliki pandangan tersendiri dalam menyikapi teori tersebut. Selain Teori Kedaulatan Hukum, terdapat juga Teori Kedaulatan Rakyat yang dikenalkan oleh J.J Rosseau, yaitu rakyatlah yang berdaulat dan mewakilkan atau menyerahkan kekuasaannya kepada negara. Kemudian negara memecah menjadi beberapa kekuasaan yang diberikan pada pemerintah,ataupun lembaga perawakilan. $^{7}$

Konsep yang dikenalkan oleh Rosseau lebih sering kita sebut dengan "Trias Politica" pembagiaan kekuasaan di suatu negara dengan tiga bagian yaitu: Legislatif, Eksekutif, dan Yudikatif. Hal tersebut membuat penulis ingin memunculkan sebuah pendapat bahwa antara kedaulatan rakyat maupun hukum keduanya bisa berjalan selaras tanpa harus dipisahkan masing-masing. Karena jika kita hanya mendasarkan pada kedaulatan hukum saja, tentu akan membuat kita bertanya, apa sumber yang mendasari pembentukan sebuah hukum. Masyarakat adalah faktor pembentuk hukum, hal ini karena hukum tidak mungkin ada dan berjalan jika tidak ada yang diatur. Artinya adalah dalam pembentukan suatu hukum tentu harus ada rakyat, karena di tengah masyarakat ada nilai dan norma yang berlaku, bilamana kedua hal tersebut menjadi kesepakatan yang mengikat, maka nilai dan norma tadi secara otomatis menjadi hukum yang sah dan tertinggi serta semua harus tunduk dibawahnya. Dalam hal itulah muncul apa yang disebut "Kedaulatan Rakyat", rakyat memiliki kewenangan dalam ikut serta menyusun apa yang akan terbit menjadi produk hukum selama hal tersebut menjadi kesepakatan yang diterima seluruh pihak. Sehingga, baik kedaulatan

2017), hlm.89.

${ }^{7}$ King Faisal Sulaiman, Teori dan Hukum Konstitusi...hlm. 83 -84. 
rakyat maupun hukum, sifatnya adalah dinamis karena masing-masing punya peran yang terkait satu sama lain. Rakyat sebagai pembentuk apa yang hendak disepakati. Apabila kesepakatan tersebut telah final maka menjadi hukum yang semua elemennya harus tunduk pada kesepakatan hukum tersebut karena mempunyai kekuatan yang mengikat subyeknya agar tunduk.

Dari pemaparan tentang teori hukum, maka bisa diaktualisasikan guna memaknai hakikat hukum terutama Konstitusi sebagai dasar bagi sebuah negara. Sesuai dengan tema yang akan dibahas, yaitu mengenai jaminan konstitusional dalam kebebasan beragama sangat diperlukan pemaknaan terhadap apa yang ada dan hendak dicapai dari kesepakatan yang tercantum dalam Konstitusi tersebut. Pasal 29 ayat 1 UUD 1945 menegaskan bahwa Negara berdasarkan Ketuhanan Yang Maha Esa. Maksudnya adalah negara mengakui keabsahan agama dalam kehidupan warga negaranya. Karena nilai-nilai tentang ketuhanan tergambar dalam satu wadah yang disebut agama, adanya pengajaran tentang tata cara peribadatan dan hakikat tentang keyakinan pada Tuhan itu sendiri. Sedangkan dalam ayat 2 dijelaskan bahwa setiap warga negara bebas untuk memeluk dan menjalankan ibadat sesuai dengan agama masing-masing dan hal tersebut dijamin dan dilindungi oleh Konstitusi. Negara menjamin bahwa setiap warga negara terbebas dari paksaan atau intimidasi dari siapapun, dan berhak menjalankan ibadat nya sesuai keyakinan tanpa adanya gangguan.

Kedaulatan Rakyat identik dengan istilah demokrasi, dimana dalam demokrasi rakyat memiliki kekuasaan tertinggi. Demokrasi mengakui hak-hak individu dan kelompok untuk merawat dan melestarikan perbedaan agama dan identitas budaya mereka. Meski demikian, demokrasi juga mengakui tanpa jaminan melalui mekanisme hukum yang jelas dan adil, problem yang mereka hadapi akan terus muncul. Masalahnya bagaimana merumuskan aturan dan mekanisme hukum tersebut menjadi tantangan tersendiri. Terlebih bagi masyarakat plural seperti Indonesia. ${ }^{8}$ Artinya, meskipun sistem demokrasi telah

${ }^{8}$ M Subhi Azhari. "Kebebasan Beragama atau Berkeyakinan dan Problem Pendirian Rumah Ibadah di Indonesia”. Jurnal HAM. Volume 11 Tahun 2014, hlm. 41. 
diterapkan, hal itu belum sepenuhnya bisa mengatasi persoalan yang ada, seperti dinamika penyusunan hukum yang ada di Indonesia. Tantangan persoalan yang dinamis, dan efektifitas dari peraturan tersebut harus tetap dievaluasi dengan baik. Sehingga apapun bentuk kedaulatan yang diambil tujuan utama yang ingin dicapai terkait jaminan hak hidup serta toleransi antar sesama dibawah payung konstitusi.

Dalam konteks kehidupan beragama juga termasuk point penting dimana konstitusi dengan jelas dan tegas memberikan jaminan dan perlindungan secara yuridis terhadap warga negaranya untuk bebas memeluk agama yang diakui di Indonesia serta menjalankan ibadat sesuai dengan agamanya masing-masing. Meskipun Konstitusi menjamin tentang kebebasan menjalankan dan mengekspresikan keyakinannya, dalam keadaan tertentu negara dapat membatasi kebebasan tersebut jikalau memang diperlukan. Hal demikian bertujuan bilamana dalam pelaksanaannya terdapat suatu hal yang bertentangan dengan Konstitusi, dan dikhawatirkan dapat menganggu stablititas nasional dan keamanan negara, serta kelompok lain. Melihat keadaan itu, negara dapat bertindak sebagai penjaga yang memberikan batas-batas yang diperlukan untuk menyikapi permasalahan tersebut. Diharapkan dengan adanya kesadaran bersama dari semua elemen bangsa tentang hakikat konstitusi, hal ini bisa mewujudkan kehidupan yang aman dan sejahtera, dengan menjunjung tinggi prinsip toleransi baik antar sesama pemeluk agama, antara umat beragama, dan hubungan antara agama dan negara.

Sehingga dari pemarapan sub bagian pertama ini, dapat penulis tarik kesimpulan bahwa Konstitusi sebagai hukum tertinggi di suatu negara dimana sifatnya mengikat dan semua peraturan yang ada dibawahnya haruslah tunduk pada Konstitusi serta baik dari pemerintah selaku penyelenggara negara, dan juga seluruh rakyat sebagai elemen bangsa haruslah tunduk dan tidak dibenarkan bila melakukan tindakantindakan yang melawan Konstitusi. Dalam Konsttusi, semua warga negara diberi hak untuk memeluk agama dan menjalankan ibadatnya dengan baik dan rasa aman, sehingga bilamana terjadi sebuah halhal yang tidak diinginkan maka Konstitusi terkait denga kebebasan beragama, penyelenggara negara wajib melakukan tindakan penegakan hukum dengan prinsip kemanusiaan dan keadilan. 


\section{Gejolak Pencabutan Rumah Ibadah di Bantul}

Sesuai dengan tema yang penulis ambil yaitu berkaitan dengan permasalahan pendirian rumah ibadah di Bantul. Jika pada bahasan sebelumnya penulis menjabarkan persoalan yuridis secara umum, maka pada sub bagian ini penulis mencoba menjabarkan persoalan yang lebih spesifik serta benar-benar terjadi di lapangan. Kasus yang penulis ambil adalah adanya gejolak potensi intoleransi dalam Pencabutan Izin Mendirikan Bangunan (IMB) Gereja Pantekosta di Desa Argorejo, Kecamatan Sedayu, Kabupaten Bantul, D.I Yogyakarta. Kasus tersebut baru mencuat ke media massa di Tahun 2019 kemarin, meskipun jika mengutip dari pemberitaan media kasus tersebut sebenarnya sudah terjadi cukup lama.

Gereja tersebut dikepalai oleh Pendeta Tigor Yunus Sitorus. Tigor Yunus Sitorus merupakan Pendeta dan Gembala Jemaat Gereja Pantekosta di Indonesia (GPdI) Immanuel Sedayu. Sebagai seorang pendeta, dia memiliki kewajiban untuk memberikan pelayanan kerohanian dan pembinaan iman terhadap jemaatnya. Pendeta Sitorus dalam melakukan aktifitas ibadah diatas bangunan rumahnya. Rumah itu yang kemudian berfungsi sebagai rumah ibadat atau Gereja. Bisa dikatakan sebuah gereja yang menjadi bagian dari jaringan gereja di tingkat gembala jemaat lokal milik organisasi keagamaan Gereja Pantekosta di Indonesia (GPdI) Sedayu. Sitorus mulai melakukan kegiatan beribadah secara rutin sejak Oktober 1997. Hal itu dibuktikan dengan surat pemberitahuan milik GPdI Sedayu Nomor 04/Pem/PPGPdI/X/1997. Saat itu, pelayanan pembinaan rohani mulai dilakukan di Perum Griya Kencana Permai, Blok CV/4, RT 04, RW 16 Dusun Bandut Lor Argorejo, Sedayu, Bantul. Pada 7 Maret 2003, Sitorus melakukan pembelian tanah pekarangan. Hal tersebut dibuktikan dengan catatan Notaris Magdawati Hadisuwito, berdasarkan Akta Jual Beli Nomor 096/2002 dan SHM 05655 dengan surat ukur No. 04261/Argor/0200/2002 seluas $335 \mathrm{~m} 2$ beralamatkan Bandot Lor RT 34 Argorejo, Sedayu, Bantul.

Tanah berupa sebuah pekarangan itu, pada tahun 2003 akhirnya dibangun oleh Sitorus menjadi sebuah bangunan untuk beribadah. Tetapi, pada proses pembangunan tempat ibadat, terdapat insiden dirobohkannya tembok bangunan oleh sekelompok warga tidak dikenal. Gereja tersebut 
awalnya adalah bangunan yang sekaligus sebagai rumah tempat tinggal Tigor Yunus dengan IMB nomor 0116/DPMPT/212/1/2019. Dengan izin tersebut, status bangunan tersebut yang semula adalah bangunan hunian yang menjadi tempat tinggal Sitorus bersama istri dan anaknya telah dijadikan sebagai tempat ibadah. ${ }^{9}$ Sejak awal, Sitorus memang akan menggunakan tempat tinggal tersebut sebagai gereja walaupun berkali-kali juga dia telah diprotes warga setempat. Oleh sebab itulah, warga protes. Itulah sebabnya yang menimbulkan terdapat narasi dari beberapa media yang menyebutkan pencabutan tersebut berkaitan dengan keberatan masyarakat beragama Islam yang khawatir terganggu keimanannya karena pelaksanaan ibadah umat lain tersebut. Seperti dikatakan bahwa warga di Dusun Gunungbulu mayoritas beragama Islam merasa terusik dengan aktivitas ibadah itu karena mayoritas ini muslim. Mereka perlu melindungi anak cucu kita agar tidak terpengaruh. ${ }^{10}$

Narasi pencabutan karena desakan umat Islam yang ingin melindungi kepentingan agamanya tersebut sebenarnya tidak tepat. Karena sebenarnya narasi pencabutan izin tersbeut lebih tepat diargumentasikan karena pendirian rumah ibadah tersebut melanggar peraturan perundang-undangan. Hal ini dibuktikan dengan hasil investigasi pihak berwenang yang telah membentuk tim bersama dengan terdiri dari Kesbangpol, bagian hukum, DMPT, dan Satpol PP. Sebagai hasil kajian, Hasilnya IMB tersebut tidak memenuhi syarat sebagaimana diatur dalam Peraturan Bupati (Perbub) Nomor 98 Tahun 2016.

Secara kronologisnya, Pada tahun 2017, Pemerintah Daerah Bantul melalui Dinas Penanaman Modal dan Pelayanan Terpadu (DPMPT) Bantul memberi sosialisasi kepada camat dan perangkat Kecamatan, Kepala Desa/Lurah dan Perangkat Desa seluruh wilayah Bantul serta kepada Penanggungjawab Tempat Ibadat yang akan mengajukan Pemutihan IMB Rumah Ibadat. Dengan itu, Sitorus mengajukan

9 Shinta Maharani “Bupati Jelaskan Alasan Cabut Izin Gereja Pantekosta Bantul", https://nasional.tempo.co/read/1230003/bupati-jelaskan-alasan-cabut-izingereja-pantekosta-bantul/full\&view=ok. Diakses 18 AGustus 2020.

${ }^{10}$ Ahmad Mustaqim, "Mengantongi IMB, Keberadaan Gereja di Bantul Ditolak Warga", https://nusantara.medcom.id/jawa-tengah/peristiwa/ybD0Mrmbmengantongi-imb-keberadaan-gereja-di-bantul-ditolak-warga. Diakses 18 AGustus 2020. 
permohonan penerbitan IMB Rumah Ibadat. Akhirnya turunlah IMB tersebut dengan rnomor 0116/DPMPT/212/1/2019.

Setelah berjalannya waktu keberadaan IMB tersebut dipermasalahkan karena terdapat hal yang tidak sesuai dengan ketentuan Peraturan Bupati. Awal mula penerbitan IMB didasari Surat Keputusan Bersama Menteri (SKB) Agama dan Menteri Dalam Negeri Nomor 9 tahun 2016 dan Nomor 8 tahun 2006. Di Kabupaten Bantul, selain berlandaskan SKB tersebut, pendirian IMB rumah ibadah juga harus meneysuaikan dengan Peraturan Bupati Nomor 98 Tahun 2016. Memang secara sekilah Perbub tentang pendirian tempat ibadah itu mengatur tentang pemutihan IMB tempat ibadah yang berdiri sebelum 2006 dan nyata-nyata digunakan sebagai tempat ibadah secara terus menerus. Tetapi Perbup tersebut memberikan persyaratan rumah ibadah yang status IMB-nya bisa diputihkan, yakni: 1. Bangunan didirikan sebelum 2006; 2. Sudah digunakan untuk tempat ibadah secara terus menerus atau permanen; 3. Bercirikan tempat ibadah; dan 4. Memiliki nilai sejarah.

Kalau bangunan Gereja tersebut memang sudah berdiri sejak 2006, tapi tidak digunakan sebagai tempat ibadah secara terus menerus. Sehingga hal itu tidak memenuhi kriteria IMB yang harus dipenuhi sebagaimana persyaratan pemerintah daerah. Atas dasar itulah, Bupati Bantul mencabut IMB GPdI Sedayu. Hal ini tertuang dalam Keputusan Bupati Bantul Nomor 345 Tahun 2019 tantang Pembatalan Penetapan GPdI Sedayu sebagai Rumah Ibadah yang Mendapatkan Fasilitas Penerbitan IMB Rumah Ibadah. ${ }^{11}$ Atas pencabutan tersebut, Pendeta Sitorus didampingi LBH Yogyakarta sempat menggugat Bupati di PTUN Yogyakarta yang pernah berjalan sejak Senin, 21 Oktober 2019. Tetapi pada akhirnya, Sitorus sepakat mencabut gugatan ke Bupati Bantul Suharsono soal pencabutan Izin Mendirikan Bangunan (IMB) gereja. Selain itu, kesepakatan diambil salah satunya karena Pendeta Sitorus menemukan lokasi baru yang hendak dibangun gereja. ${ }^{12}$

${ }^{11}$ Irwan Syambudi, Baca selengkapnya di artikel "Bupati Bantul Cabut IMB Gereja yang Ditolak Warga", https://tirto.id/effy...https://tirto.id/bupati-bantul-cabutimb-gereja-yang-ditolak-warga-effy. Diakses 18 Agustus 2020.

${ }^{12}$ Irwan Syambudi, Baca selengkapnya di artikel "Gugatan Gereja GPdI Bantul Berakhir Damai, Pendeta Bersedia Pindah”, https://tirto.id/eroy. https://tirto. 


\section{Analisis Pencabutan Izin Rumah Ibadah Beradasrkan Hukum Negara}

Indonesia sebagai negara yang menjadikan hukum sebagai kedaulatan yang mewakili rakyat. Hal demikian dimaksud untuk mencapai sebuah kesepakatan yang adil bagi segenap elemen bangsa. Dengan menjadikan hukum sebagai landasan utama dan posisi tertinggi, diharapkan bisa menjadi pedoman untuk menjalani kehidupan berbangsa dan bernegara dengan baik, tanpa mengabaikan aspek-aspek kepentingan tertentu saja. Konsep demikian dapat dipahami bahwa hukum itu netral dan tidak memihak siapapun, adanya prinsip yang disebut "equality before the law" atau persamaan didepan hukum menjadikan penulis berpandangan bahwa konsep tersebut cukup relevan untuk mencari sebuah jalan tengah dari persoalan yang dihadapi tanpa mengabaikan hak masing-masing individu ataupun kelompok.

Kebebasan beragama menjadi salah satu aspek penting yang posisinya mendapatkan jaminan serta perlindungan bagi setiap pemeluknya terutama dalam menjalankan ibadatnya. Beragama adalah hak dasar yang dimiliki setiap individu ketika hidup, hak ini terus melekat dan tidak dapat untuk dicabut ataupun dihilangkan, melainkan dapat dibatasi bila diperlukan. Hak dasar tersebut lebih sering disebut Hak Asasi Manusia (HAM). Hak tersebut dibawa seorang individu, bahkan ketika individu tersebut masih berada dalam kandungan hingga ia lahir dan akan terus melekat sampai orang tersebut meninggal dunia. sebuah hak kodrati pemberian Tuhan yang berlaku secara universal tanpa terikat oleh batas-batas wilayah, maupun waktu.

Kebebasan beragama merupakan hak fundamental yang merupakan salah satu hak dari 16 hak yang tidak dapat dikurangi dalam keadaan apapun (non-derogable rights). Hak untuk beragama merupakan hak yang tidak dapat diambil oleh siapapun (unalienable) karena hak untuk beragama ditentukan oleh dirinya sendiri tanpa ada paksaan dan dipaksakan, oleh karena itu dalam pelaksanaannya negara dalam hal ini tidak boleh melakukan intervensi terhadap kebebasan beragam akan

id/gugatan-gereja-gpdi-bantul-berakhir-damai-pendeta-bersedia-pindah-eroy. Diakses 18 Agustus 2020. 
tetapi harus dapat memberikan suatu jaminan kepada warga negaranya untuk menjalankan agamanya tanpa ada gangguan dari pihak manapun. ${ }^{13}$

Perlu diketahui bahwa dalam konteks perundang-undangan, walaupun kebebasan beragama dan berkeyakinan merupakan hak asasi yang mutlak, tetapi dalam teoritisasinya terdapat dua dimensi. Dimensi pertama adalah kebebasan dalam forum internum. Kebebasan dalam forum internum tersebut adalah kebebasan untuk memilih agama. Dimensi kedua adalah kebebasan dalam forum eksternum. Kebebasan dalam forum eksternum tersebut termasuk salah satu contohnya adalah pendirian rumah ibadah. Apa yang dilakukan oleh Pemerintah Kabupaten Bantul tersebut sudah sesuai dengan peraturan perundangundangan. Pasal 28J ayat 2 UUD 1945 telah memberikan legalitas pembatasan kebebasan beragama, yang salah satu persyaratannya adalah untuk melindungi ketertiban dan keamanan. perihal pendirian rumah ibadah sudah termuat dalam Peraturan Bersama Menteri Agama dan Dalam Negeri Nomor 9 dan 8 Tahun 2006 Tentang Pendirian Rumah Ibadah dan Pemberdayaan Forum Kerukunan Umat Beragama. Banyak kalangan yang menilai bahwa lahirnya PBM tersebut masih menimbulkan polemik, yang mana ada beberapa syarat-syarat terkait pendirian rumah ibadah yang dinilai mengandung unsur diskriminasi. Tetapi keberadaan Peraturan Bersama tersebut, yang kemudian dalam konteks ini diperjelas dalam Peraturan Bupati Bantul merupakan salah satu sarana terlaksananya pendirian rumah ibadah untuk tetap menjaga kerukunan dan ketentraman. Kebebasan forum internum tidak bisa dibatasi, sementara forum eksternum bisa dibatasi. ${ }^{14}$

${ }^{13}$ Nella Sumika Putri. "Pelaksanaan Kebebasan Beragama di Indonesia (External Freedom) Dihubungkan Ijin Pembangunan Rumah Ibadah". Jurnal Dinamika Hukum Vol. 11 No. 2 Mei 2011.

${ }^{14}$ Faiq Tobroni, "Pembatasan Kegiatan Keagamaan Dalam Penanganan Covid-19”, Jurnal Komunikasi Hukum (JKH), Volume 6 Nomor 2 Tahun 2020, 369-395, lihat juga Faiq Tobroni, "Pembedaan Kebebasan Beragama dan Penodaan Agama", Al-Jinayah: Jurnal Hukum Pidana Islam, Volume 5 Nomor 2 Tahun 2019, 489-510, dan lihat juga Faiq Tobroni, "Keterlibatan Negara dalam Mengawal kebebasan Bearagam/Berkeyakinan”, Jurnal Konstitusi Volume 7 Nomor 6 Tahun 2010 . 
Pencabutan yang dilakukan Pemerintah Kabupaten Bantul terhadap gereja tersebut termasuk dalam kategori pembatasan. Konsep pembatasan dalam HAM berbeda dengan konsep pengurangan (derogasi). Derogasi adalah mekanisme suatu negara menyimpangi tanggung jawabnya secara hukum karena adanya situasi yang darurat ${ }^{15}$. Derogasi dijalankan dengan syarat keadaan darurat yang mengancam kelanjutan hidup, keamanan, disintegrasi bangsa dan negara dapat secara resmi mengumumkannya. ${ }^{16}$ Terdapat kriteria ketika negara melakukan derogasi. Seperti, syarat penyebab adanya keadaan darurat yang sesuai dengan perjanjian internasional. Selain pembatasan hak harus ditetapkan melalui proses hukum, pembatasan hak juga harus memenuhi prinsip proporsional. Penetapatan keadaan darurat harus memenuhi asas deklarasi, legalitas, komunikasi, kesetaraan, keistimewaan ancaman, proposionalitas, intangibility dan pengawasan ${ }^{17}$. Tindakannya dapat memuat bahwa kepala negara mengumumkan kepada publik secara resmi bahwa keadaan negaranya sedang bahaya. Serta, kepala negara wajib memberitahu kepada negara lain melalui Sekretaris Jendral Perserikatan Bangsa-Bangsa. ${ }^{18}$ Adapun haknya seperti, hak untuk menyatakan pendapat, hak untuk bergerak, hak untuk berkumpul, dan hak untuk berbicara. Kedaan darurat atau public emergency, terdapat unsur yang menyertainya seperti, bersifat sementara waktu, untuk mengatasi keadaan krisis dan mengembalikan kepada keadaan normal. Bisa dikatakan bahwa "Kebijakan pengurangan lebih tepatnya digunakan untuk menangani situasi Darurat Sipil dan Militer. Darurat Sipil terjadi karena kekerasan massif seperti konflik di Aceh (2002) dan di Maluku (2000). Sementara, Darurat Militer terjadi karena perang saudara atau pemberontakan seperti di Timor Timur (1999) dan di Aceh (2003)." 19

${ }^{15}$ Knut Asplund, Suparman Marzuki dan Eo Riyadi (Ed.) Hukum Hak Asasi Manusia ( Yogyakarta: PUSHAM UII, 2008), hlm. 41.

${ }^{16}$ Osgar S. Matompo, "Pembatasan Terhadap Hak Asasi Manusia Dalam Pesrpektif Keadaan Darurat”, Jurnal Media Hukum, Vol. 21 No.1 Juni 2014.

${ }^{17}$ Ibid.

${ }^{18}$ Eko Riyadi, Hukum Hak Asasi Manusia: Perspektif Internasional, Regional dan Nasional, (Jakarta: Rajawali Press, 2018), hlm. 50-52.

${ }^{19}$ Agus Adhari, "Ambiguitas Pengaturan Keadaan Bahaya Dalam Sistem Ketatanegaraan Indonesia”, Jurnal Dialogia Iuridica, Volume 11 Nomor 1, November 
Sementara itu, pembatasan berlaku pada keadaan normal. Walaupun begitu, negara tidak secara gampang melakukan sebuah pembatasan HAM, ada ketentuan yang menyertainya. Prinsip prinsip Siracusa mengatur pembatasn hak, terdapat di dalam poin B. Prinsip-prinsip penafsiran yang berhubungan dengan ketentuan-ketentuan pembatasan yang bersifat khusus ${ }^{20}$, antaranya: "ditetapkan oleh hukum", "dalam masyarakat demokratis", "ketertiban umum", "kesehatan masyarakat", "moral publik", "keamanan nasional", "keselamatan publik", "hak dan kebebasan orang lain," atau "hak dan reputasi orang lain", dan "pembatasan pada pengadilan umum".

Secara teoritik, pembatasan hak beragama terdiri dari dua macam: forum internum dan forum eksternum. ${ }^{21}$ Ciri dari forum internum, sesuatu hak yang berlaku absolut. Artinya, hak ini tidak dapat dibatasi dalam keadaan apapun walau publik sedang darurat. Forum internum memiliki nilai kebebasan yang tidak terlihat secara lahiriyah. Semisal dalam beragama yakni, memiliki atau menganut agama atau kepercayaan berasal dari dalam dirinya. Forum internum menyangkut kebebasan beragama yang bersifat abstrak. Karena, ada dalam lubuk hati dan sanubari manusia. Hanya manusia yang meyakini agama-agama yang mampu mendefinisikan keyakinan sebagai bagian dari forum internum.

Selanjutnya, forum eksternum, yaitu kebebasan untuk mengungkapkan atau memanifestasikan agama atau keyakinan dalam bentuk secara nyata. Karenanya, forum eksternum dapat dibatasi. Sebab, tindakannya dalam bentuk ritual yang termanifestasikan dari ajaran agama dan keyakinan yang dianut oleh manusia memuat hak orang lain di dalamnya. Secara prinsipil, bentuk forum eksternum antara lain menjalankan agama dan kepercayaannya dalam kegiatan ibadah, memiliki tempat ibadah, menggunakan/memakai simbol-

$2019,43-61$.

${ }^{20}$ Asep Mulyana, Prinsip-prinsip Siracusa mengenai Ketentuan Pembatasan dan Pengurangan Hak Asasi Manusia (HAM) dalam Kovenan Internasional tentang Hak Sipil dan Politik, Annex, UN Doc E / CN.4 / 1984/4 (1984).

${ }^{21}$ Muwaffiq Jufri, "Pembatasan Terhadap Hak dan Kebebasan Beragama di Indonesia", Jurnal Ilmiah Pendidikan Pancasila dan Kewarganegaraan, Vol. 1, Nomor 1, Juni 2016. 
simbol agama, memperingati hari-hari besar keagamaan, menunjuk atau memilih pemimpin agama, mengajarkan dan menyebarkan bahan-bahan keagamaan, melakukan siar agama, hak orang tua untuk memastikan pendidikan agama dan moral bagi anak-anak mereka, berkomunikasi dengan individu dan komunitas tentang urusan agama di tingkat nasional dan internasional, mendirikan dan menjalankan lembaga-lembaga kemanusiaan/mengumpulkan dan menerima pendanaan. ${ }^{22}$

Dengan demikian bisa dikatakan bahwa pencabutan IMB gereja tersebut bagian dari pembatasan yang dilakukan oleh Negara. Pembatasan tersebut memang diperbolehkan oleh peraturan perundang-undangan dalam rangka menjaga kerukunan dam ketertiban. Hal ini disebabkan karena pada dasarnya kebebasan membuat tempat ibadah termasuk kategori forum eksternum. Kategori ini bisa dibatasi termasuk dengan kehadiran peraturan kepala daerah yang membuat peraturan mengenai mekanisme pembuatan rumah ibadah. Selama ketentuan tersebut tidak bertentangan dengan peraturan di atasnya, maka peraturan tersebut bisa berjalan. Tetapi apabila peraturan kepala daerah tersebut bertentangan dengan peraturan di atasnya, maka warga Negara berhak melakukan judicial review terhadap peraturan tersebut.

\section{Penutup}

Secara umum pencabutan izin rumah ibadah bisa dianggap sebagai pembatasan hak untuk melaksanakan kebebasan beragama dan berkeyakinan. Peraturan perundang-undangan nasional seperti Pasal 28J UUD 1945 dan Pasal 70 serta 73 UU 39/1999 memang mengatur tentang kewenangan Negara melakukan pembatasan. Begitujuga dalam Kovenan Internasional Hak Sipil dan Politik Pasal 18 ayat 3 juga mengatur kewenangan Negara melakukan pembatasan kegiatan keagamaan seperti pendirian rumah ibadah. Tetapi yang harus diingat, pembatasan tersebut harus dilaksanakan sesuai dengan peraturan perundangundangan. Pembatasan atas kebebasan perorangan maupun kelompok dalam menjalankan ajaran agamanya atau kepercayaannya melalui

${ }^{22}$ Zainal Abidin Bagir, dkk, Membatasi Tanpa Melanggar Hak Kebebasan Beragama atau Berkeyakinan, (Yogyakarta: Center for Religious and Cross-cultural Studies (CRCS), 2019), hlm. 5-6., 
mekanisme ketentuan berdasarkan hukum. Sebagai persyaratannya, negara tersebut harus mampu membuktikan bahwa pembatasannya diperlukan dalam rangka melindungi keamanan, ketertiban, kesehatan, atau moral masyarakat, atau hak-hak dan kebebasan mendasar orang lain.

\section{Daitar Pustaka}

Adhari, Agus., "Ambiguitas Pengaturan Keadaan Bahaya Dalam Sistem Ketatanegaraan Indonesia”, Jurnal Dialogia Iuridica, Volume 11 Nomor 1, November 2019.

Asplund, Knut., Suparman Marzuki dan Eo Riyadi (Ed.) Hukum Hak Asasi Manusia ( Yogyakarta: PUSHAM UII, 2008).

Asshiddiqie, Jimly., Pengantar Ilmu Hukum Tata Negara Jilid I (Jakarta: Sekretariat Jenderal dan Kepaniteraan MK RI, 2006).

Azhari, M Subhi., "Kebebasan Beragama atau Berkeyakinan dan Problem Pendirian Rumah Ibadah di Indonesia”. Jurnal HAM. Volume 11 Tahun 2014.

Bagir, Zainal Abidin., dkk, Membatasi Tanpa Melanggar Hak Kebebasan Beragama atau Berkeyakinan, (Yogyakarta: Center for Religious and Cross-cultural Studies (CRCS), 2019).

Jufri, Muwaffiq., "Pembatasan Terhadap Hak dan Kebebasan Beragama di Indonesia", Jurnal Ilmiah Pendidikan Pancasila dan Kewarganegaraan, Vol. 1, Nomor 1, Juni 2016.

Maharani, Shinta., "Bupati Jelaskan Alasan Cabut Izin Gereja Pantekosta Bantul", https://nasional.tempo.co/read/1230003/ bupati-jelaskan-alasan-cabut-izin-gereja-pantekosta-bantul/ full\&view=ok. Diakses 18 Agustus 2020.

Matompo, Osgar S. ., "Pembatasan Terhadap Hak Asasi Manusia Dalam Pesrpektif Keadaan Darurat”, Jurnal Media Hukum, Vol. 21 No.1 Juni 2014.

Mulyana, Asep., Prinsip-prinsip Siracusa mengenai Ketentuan Pembatasan dan Pengurangan Hak Asasi Manusia (HAM) dalam 
Kovenan Internasional tentang Hak Sipil dan Politik, Annex, UN Doc E / CN.4 / 1984/4 (1984).

Mustaqim, Ahmad., "Mengantongi IMB, Keberadaan Gereja di Bantul Ditolak Warga", https://nusantara.medcom.id/jawa-tengah/ peristiwa/ybD0Mrmb-mengantongi-imb-keberadaan-gereja-dibantul-ditolak-warga. Diakses 18 Agustus 2020.

Putri, Nella Sumika., "Pelaksanaan Kebebasan Beragama di Indonesia (External Freedom) Dihubungkan Ijin Pembangunan Rumah Ibadah". Jurnal Dinamika Hukum Vol. 11 No. 2 Mei 2011.

Riyadi, Eko., Hukum Hak Asasi Manusia: Perspektif Internasional, Regional dan Nasional, (Jakarta: Rajawali Press, 2018).

Sulaiman, King Faisal., Teori dan Hukum Konstitusi (Bandung: Nusa Media, 2017).

Syambudi, Irwan., "Bupati Bantul Cabut IMB Gereja yang Ditolak Warga", https://tirto.id/effy...https://tirto.id/bupati-bantul-cabutimb-gereja-yang-ditolak-warga-effy. Diakses 18 Agustus 2020.

Syambudi, Irwan., "Gugatan Gereja GPdI Bantul Berakhir Damai, Pendeta Bersedia Pindah", https://tirto.id/eroy. https://tirto.id/ gugatan-gereja-gpdi-bantul-berakhir-damai-pendeta-bersediapindah-eroy. Diakses 18 Agustus 2020.

Tobroni, Faiq., "Keterlibatan Negara dalam Mengawal kebebasan Bearagam/Berkeyakinan", Jurnal Konstitusi Volume 7 Nomor 6 Tahun 2010.

Tobroni, Faiq., "Pembatasan Kegiatan Keagamaan Dalam Penanganan Covid-19”, Jurnal Komunikasi Hukum (JKH), Volume 6 Nomor 2 Tahun 2020.

Tobroni, Faiq., "Pembedaan Kebebasan Beragama dan Penodaan Agama", Al-Jinayah: Jurnal Hukum Pidana Islam, Volume 5 Nomor 2 Tahun 2019.

Undang - Undang Dasar 1945.

Yunus, Firdaus M. "Konflik Agama Di Indonesia Problem Dan Solusi Pemecahannya”. Substantia, Volume 16 Nomor 2, Oktober 2014. 